\title{
The Role of the Quality of Institutions in the Financial Development of CEMAC Countries
}

\section{Pierre Ghislain Batila Ngouala Kombo, Guénolé Bongo Koumou}

Faculty of Economic Sciences and Laboratory of Economic and Social Research and Studies (LARES), Université Marien Ngouabi, Brazzaville, Congo

Email: ghislain.batila@umng.cg, gmbongo@hotmail.fr

How to cite this paper: Batila Ngouala Kombo, P. G., \& Bongo Koumou, G. (2021). The Role of the Quality of Institutions in the Financial Development of CEMAC Countries. Modern Economy, 12, 452-468.

https://doi.org/10.4236/me.2021.122023

Received: January 6, 2021

Accepted: February 23, 2021

Published: February 26, 2021

Copyright $\odot 2021$ by author(s) and Scientific Research Publishing Inc. This work is licensed under the Creative Commons Attribution International License (CC BY 4.0).

http://creativecommons.org/licenses/by/4.0/

\begin{abstract}
The quality of institutions is increasingly recognized as an indispensable factor in investment, business climate and resource allocation. In this regard, the purpose of this paper is to analyze the role of institutional quality in the financial development of CEMAC countries. Using panel data over the period 2002 to 2018 and the DOLS technique, it is found that, on the one hand, the quality of regulation and political stability generally reduce the level of financial development in the CEMAC, and on the other hand, the control of corruption and compliance with laws and regulations contribute positively to the CEMAC's financial development. These results make it possible to identify the implications of economic policies aimed at improving the quality of institutions.
\end{abstract}

\section{Keywords}

Institutional Quality, Financial Development, Central Africa

\section{Introduction}

Since Schumpeter (1912), several authors (Gurley \& Shaw, 1960; Goldsmith, 1969; etc.) have emphasized the importance of the role that the development of the financial system can play in the growth process. However, restrictions on financial activity can hinder the development of the financial system and thus constitute an obstacle to growth. To reduce financial restrictions, McKinnon (1973) and Shaw (1973) proposed reforms to allow the development of the financial system. These reforms were essentially based on the liberalization of interest rates.

Given the importance attached to the theory of financial liberalization, many developing countries have taken measures to reform their financial systems with 
the aim of reviving financial activity. However, the results of these reforms have not met expectations (Mahar \& Williamson, 1998). Reforms have been successful in some countries (e.g., Indonesia and South Korea) but failed in others (particularly in some Latin American countries). The mixed results of these reforms have raised questions among both policymakers and economists about the effectiveness of these financial liberalization policies and their ability to support the development of financial systems.

Several arguments have been put forward to justify the failures of the financial liberalization policies implemented in most developing countries. For neo-Keynesians (Stiglitz \& Weiss, 1981; Cho, 1986), the credit market is subject to information asymmetries and transaction costs that prevent reforms from being effective. Neo-structuralists (Van Wijnbergen, 1983) consider that it is not possible to undertake a liberalization policy without taking into account the informal financial sector. For new institutional economists, the performance of the financial system cannot result solely from economic factors but is also influenced by noneconomic factors, in particular the quality of institutions (regulatory standards, law enforcement, property rights, transparency and supervision). Currently, economists (North, 1990; La Porta et al., 1997) and financial institutions (IMF and World Bank) agree that institutional quality is necessary for financial development.

Moreover, in the economic literature, several studies (theoretical and empirical) have been carried out to show that there is a real relationship between the quality of institutions and financial development. On the theoretical level, three theories (the theory of law and finance, the theory of endowments and the theory of pressure groups) offer conflicting explanations for the role of the quality of institutions in financial development. For the first theory, differences in the level of financial development are explained by the historical and conceptual origins of legal systems (La Porta et al., 1998). In contrast to the first, the second theory states that the initial conditions and resources explain the levels of financial development (Acemoglu et al., 2001). In contrast, according to the third theory, pressure groups are responsible for the non-monotonic evolution of financial development (Rajan \& Zingales, 2003).

These theoretical contributions have given rise to numerous empirical works whose results regarding the role of institutional quality in the development of financial systems remain controversial. For example, Ayadi et al. (2013) analyze the impact of macroeconomic and institutional variables on the financial development of northern and southern Mediterranean countries over the period 1985-2009 and find that quality institutions, good governance and the proper implementation of financial reforms have a positive impact on financial development. Conversely, Cherif and Gazdar (2010) study the role of institutional quality in financial development and conclude that institutional quality does not have a significant effect on the level of financial development, and in some cases, it may even hinder financial development.

From the above, it appears that the theoretical and empirical debates on the 
role of institutional quality in financial development are not yet closed. To further explore this issue, the CEMAC zone is a particularly interesting area of study because of the implementation of financial sector reforms over the last two decades.

Indeed, CEMAC countries, like other developing countries, have taken steps towards financial liberalization. When the related reforms were first implemented, these countries had repressive economies characterized by a predominance of banks with a high level of state participation in their capital. The stock markets were embryonic, and their contribution to the activities of the financial system was very low. In addition, local banks were responsible for financing investments and guaranteeing defaulting public sector firms, which led them to accumulate a large volume of nonperforming loans. After more than a decade of financial reforms, the financial system of CEMAC countries has undergone profound restructuring. These have focused on the liquidation of many financial institutions, the privatization of the remaining institutions, the end of the direct state regulation of credit and financial institutions, the establishment of independent monetary regulatory authorities and the adoption of stricter prudential regulations (Joseph, 2002).

Despite these restructurings, there are significant regulatory and practical imperfections in the financial markets of CEMAC countries. On the regulatory front, the banks in these countries struggle to finance a vibrant private sector operating within a legal framework that lacks ownership status, is not very transparent and is little conducive to the enforcement of financial contracts, debt collection and collateral mobilization. At the practical level, it should be emphasized that most of these banks are constrained by the opacity of the financial information that should guide their credit policy. Thus, in the absence of financial information, they find refuge in the risk premium that creates a spread between the key rate and the rate served to clients.

Hence, financial institutions concerned with granting credit face the problem of information asymmetry and lack of transparency. This explains why the ratio of bank credits of the private sector to GDP, which reflects financial depth, never exceeded 25\% of GDP, on average, over the period 1960-2016 in CEMAC countries, while in emerging countries such as China, Korea, Singapore and Thailand, the ratio was $156.7 \%, 143.3 \%, 147.3 \%$ and $132.9 \%$, respectively, in 2016 .

Similarly, the low level of long-term credit granted to the economies of CEMAC countries is linked to macroeconomic and political uncertainty. This uncertainty (macroeconomic and political) justifies the fact that the rate of financing of the economy by the financial system of these countries remains relatively low, over 12\% in 2012 according to the Banque de France 2017, compared to the rates observed in emerging countries (35\% in Brazil, $37 \%$ in India and $120 \%$ in China).

Additionally, this system continues to be influenced by public authorities since the BEAC continues to lend to governments at advantageous rates, which contradicts the spirit of financial liberalization and is therefore detrimental to 
the strategic development of the zone's financial system. Finally, the legislative framework of CEMAC countries is, above all, poorly adapted to the economic realities of countries characterized by low institutional quality. In this regard, the Mo Ibrahim Report (2019) shows that compared to other areas of the continent (West Africa, East Africa and the Maghreb), the CEMAC zone has the worst performance in terms of governance. Thus, these institutional weaknesses may constitute one of the impediments to the development and efficiency of the financial systems of these countries.

Under these conditions, the question that arises from the above developments is the following: what is the effect of the quality of institutions on the financial development of CEMAC countries? To address this issue, this article analyzes the effect of the quality of institutions on the financial development of CEMAC countries. Based on the experience of Southeast Asian countries and countries in transition, we postulate that an improvement in the quality of institutions promotes the financial development of the countries of the subregion. Indeed, according to Arestis et al. (2002), financial reforms can promote financial sector development only when the economic system is anchored in a sound, credible and adequate legal and institutional structure.

In addition to the introduction, this article is structured as follows. In the second section, we briefly review the literature related to the object of the study. The third section is devoted to the presentation of the empirical model, the estimation method and the data. In the fourth section, we assess the effect of the quality of institutions on the financial development of CEMAC countries. Based on this, the main results are reported and interpreted. A conclusion and policy implications are presented in the last section.

\section{Literature Review}

The question of the role of institutions in financial development is the subject of abundant literature, whose theoretical and empirical features are presented here.

On the theoretical level, it should be noted that the relationship between the quality of institutions and financial development has given rise to debates that pit several theories against each other: the theory of law and finance, the theory of endowments and the theory of pressure groups.

The theory of law and finance, initiated by the work of La Porta et al. (1998), states that it is the historical and conceptual origin of legal systems that represents the origin of the differences between financial systems. This theory states that in a country where the legal system facilitates contracts between private agents and protects private property rights and investors' rights, savers are inclined to invest in firms, thus contributing to the expansion of financial markets. Conversely, a system that offers very little protection of property rights and investors' rights tends to hinder financial development. Second, this theory emphasizes that the legal origin of the judicial system may explain the differences between countries in the protection of investors' rights and contracts and the 
level of financial development. From this perspective, La Porta et al. (1997) argue that civil law tends to protect private property rights less than common law, which explains why countries that have adopted common law have more developed financial systems.

Unlike legal and financial theory, which focuses on the identity and origin of colonizers to define the quality and efficiency of a country's institutions, endowment theory is interested in the initial conditions and resources of colonized countries. From this perspective, Acemoglu et al. (2001) consider that the colonizers' settlement strategy is a function of the endowments that the colonized country enjoys, with tangible consequences on institutions, including financial institutions. Thus, in an extractive economy, occupiers do not ensure the establishment and development of free and competitive financial markets, as this would risk compromising their acquired position. In the case of a settlement economy, on the other hand, occupants try to build institutions that protect private property rights and thus contribute to financial development.

For pressure group theory, the nonmonotonic evolution of financial development is explained by the fact that pressure groups oppose it because financial development generates competition. Thus, for Rajan and Zingales (2003), the process of financial development is not always "win-win", and there is always a "win-lose" situation. Winners press to delay financial development as much as possible. They are reluctant to change, and financial development can only take place if their influence on political authorities weakens.

Thus, in contrast to La Porta et al. (1997, 1998), Rajan and Zingales (2003) consider political factors to be more decisive than legal traditions in achieving financial development. According to this approach, when a given group seizes power, it sets up policies and institutions to its benefit (North, 1990). Under these conditions, a strong and centralized government is incompatible with a developed financial system, especially in the presence of an elite whose power would be threatened by financial development. The explanation for this assertion is that the proper functioning of financial institutions requires less discretion on the part of the government, which may be incompatible with the ambitions and other designs of a strong central government. A strong government cannot promise to honor its credit (repayment) commitments, which can weaken the lending financial institutions or even the entire financial system. On the other hand, a decentralized and democratic government structure can provide an environment that is more conducive for financial development.

These theoretical considerations have given rise to numerous empirical studies with ambiguous and controversial results. Thus, a series of works applying GMM, MCGR, and PMG to panel data has analyzed the factors likely to explain the level of financial development of groups of countries. Some studies have concluded that the quality of institutions positively affects the level of financial development in some countries. With this in mind, Girma and Shortland (2008) have shown that the level of financial development in developed and developing countries is explained by the degree of democracy and political stability. For Law 
and Habibullah (2009), the quality of institutions has a positive effect on the credit to the private sector provided by banks and on the market capitalization of European, East Asian, Latin American and G-7 countries over the period 1980-2001.

By examining the impact of macroeconomic and institutional variables on financial development, Gazdar (2011) showed that institutional factors (political risk, rule and law, democratic credibility, and quality of bureaucracy) well explain the level of financial development in MENA countries. Similarly, Ayadi et al. (2013) showed the positive impact of institutional factors (strong legal institutions, good governance and adequate implementation of financial reforms) on the financial development of northern and southern Mediterranean countries between 1985 and 2009. Yasmina and Mohamed (2016) concluded that institutional quality, as captured by an index reflecting the capacity of governments to formulate and implement good policies as well as the degree of compliance with institutions among citizens and governments, is the most significant determinant of financial development in the MENA region over the period 1996-2011.

Other studies, however, have observed a negative effect of the quality of institutions on financial development. This is the case of Béji (2009), who shows for a sample of Southern Mediterranean countries that the relationship between financial development and institutional development is statistically nonsignificant. Similarly, the results of Cherif and Gazdar (2010) reveal that institutional quality does not have a significant effect on financial market development in the MENA region. In the same vein, the results of Béji and Youssef (2010) indicate the absence of a significant relationship between the level of institutional development and banking development in 19 MENA countries over the period 1982-2005. The authors explain this result by the specificity of the institutional variables that change very slowly over time.

In the context of African countries, the results are also controversial. For example, Anayiotos and Toroyan (2009) and Gries et al. (2009) find a positive impact of institutional factors, such as the protection of property rights and political stability, on financial sector development in Sub-Saharan Africa. Similarly, Demetriades and Fielding (2009) show that corruption and political instability are major challenges to financial development in West African countries. Ahokpossi et al. (2012), in a comparative study between WAEMU countries and other SSA countries, show that a strong rule of law and institutional infrastructure as well as the collection and dissemination of credit information leads to an increase in bank lending to the private sector. In their studies of the relationship between institutional structure and the level of financial market development in 40 African countries over the period 2009-2015, Agyemang et al. (2018) show that good institutional infrastructure stimulates the level of financial market development in Africa.

On the other hand, Ghura et al. (2009) explain the low level of financial deepening in the CFA franc zone compared with other SSA countries by pointing to 
differences in the quality of institutions related to the protection of property rights and the dissemination of credit information. Using an index of institutional quality, Bodjongo and Juliot (2012) concludes that the poor quality of institutions in CEMAC countries largely explains their weak financial development.

Two lessons can be drawn from this literature review. The first is that no consensus is yet possible based on either theoretical or empirical contributions. The role of institutional quality is still an open question, and further investigation is needed. This is why the study context of the CEMAC countries is fully justified insofar as this issue is still very little studied.

The second lesson relates to the methodology used to analyze the relationship between institutional quality and financial development. Indeed, to analyze the factors that may explain the level of financial development of groups of countries, authors have used generalized method of moments (GMM), generalized least squares (GLS), and pooled mean group (PMG). In this paper, we use DOLS techniques to test the role of institutional quality in the financial development of CEMAC countries. The DOLS approach is appropriate in the case of the CEMAC because it involves a small number of individuals ( 6 countries) and a small number of observations (11 years).

\section{Methodology}

The model describing the effects of institutional quality on financial development is presented first, and then, the data sources and their descriptions are presented.

\subsection{Analysis Model and Study Data}

The literature presented above helps establish the link between institutional quality and financial development. In the case of the CEMAC zone, this link is analyzed by drawing on the work of Law \& Azman-Saini (2008). According to these authors, financial development is a function of the quality of institutions and other macroeconomic factors. Let the implicit form be as follows:

$$
D F_{i t}=f\left(I N S T_{i t}, C_{i t}\right)
$$

where $D F_{i t}$ represents the degree of financial development; it is a function of both the vector of institutional variables $\left(I N S T_{i t}\right)$ and the vector of control variables $\left(C_{i t}\right)$.

Assuming that the process of financial development is dynamic, our first equation can be written as follows:

$$
D F_{i t}=f\left(D F_{i t-1}, I N S T_{i t}, C_{i t}\right)
$$

Taking the logarithms, we obtain the following equation:

$$
\ln D F_{i t}=\beta_{0}+\beta_{1} \ln D F_{i t-1}+\beta_{2 i} \ln C_{i t}+\beta_{3 i} I N S T_{i t}+u_{i}+\varepsilon_{i t}
$$

However, the literature indicates that a developed financial sector is positively associated with greater trade and financial openness (Rajan \& Zingales, 2003; Huang \& Temple, 2005). Therefore, in Equation (3), we add trade openness. 
Thus, the basic equation for financial development is as follows:

$$
\ln D F_{i t}=\beta_{0}+\beta_{1} \ln D F_{i t-1}+\beta_{2 i} I N S T_{i t}+\beta_{3} \ln P I B_{i t}+\beta_{4} \ln O C_{i t}+\mu_{i}+\varepsilon_{i t}
$$

\subsection{Data Source and Presentation of Variables}

Annual data covering the period 2002 to 2018 are used in this study. Data on macroeconomic variables (inflation and GDP) and institutional quality come from the World Bank's database. Data on financial development come from the database of the Bank of Central African States. The choice of this period is essentially dictated by the availability of data on institutional variables. The data concern the six CEMAC ${ }^{1}$ countries: Cameroon, CAR, Congo, Gabon, Equatorial Guinea and Chad. The panel analysis is thus justified by the lack of data over a long period of time in each country.

For the purposes of this work, we retained the following variables: gross domestic product (GDP); the inflation rate $(\pi)$, measured on the basis of the consumer price index; trade openness (TO), measured by the ratio of the total value of trade (exports plus imports) to GDP; and four variables on the quality of institutions (quality of regulation, control of corruption, rule and law, and political stability). These variables are summarized in Table 1 below.

Table 1. Variables, authors and expected signs.

\begin{tabular}{lccc}
\hline & Variables & Authors & Expected-sign \\
\hline Financial Development Indicators & M2/GDP & Bodjongo \& Juliot (2012) & \\
\hline & Quality of regulation & & + \\
& Control of corruption & Cherif \& Gazdar (2010) & - \\
Rulicators of institutional quality & Rolitical stability & Roe \& Siegel (2009) & + \\
& Real GDP per capita & Law \& Azman-Saini & + \\
& Trade openness & Rajan \& Zingales, 2003 & + \\
\hline
\end{tabular}

Source: Authors, from the literature.

\section{Estimation Method and Technique}

\subsection{Estimation Method}

The estimation of this model by the OLS technique leads to nonconvergent estimators due to the asymptotically biased distribution associated with the presence of serial autocorrelation in the data (Kao \& Chen, 1995; Pedroni, 2001; Kao \& Chiang, 2001). These problems, which also exist in the case of models specified in the form of time series, are also present and even acutely so in the case of panel models, particularly in the presence of heterogeneity (Kao \& Chen, 1995). Such is, in this work, the case of the CEMAC, which is a heterogeneous monetary union (Tapsoba, 2009). Other methods are often used in the literature to ${ }^{1}$ Economic and monetary community of central Africa. 
correct various biases. These include modified least squares (MLS) and the dynamic ordinary least squares method. The FMOLS method can address the biases of the endogeneity of exogenous variables, autocorrelation and heteroskedasticity.

However, by looking at the properties of the OLS, FMOLS and DOLS estimators in small finite samples, Kao and Chiang (2001) showed that OLS estimators are biased and FMOLS estimators do not provide substantial improvements, thus concluding that the DOLS estimator provides the best results. This justifies the use of this approach in this study.

Indeed, the DOLS approach is appropriate in the case of the CEMAC because the data cover a small number of individuals ( 6 countries) and a small number of observations (11 years). In panel data, Kao and Chiang (2001) and Mark and Sul (2003) describe this technique, which consists of including advanced and delayed values of exogenous variables in the model to eliminate the correlation between the explanatory variables and the error term.

\subsection{Estimation Technique}

Before performing the econometric analysis, we will first describe the variables used for this study and verify the existence or absence of a unit root in the data and of cointegration in the panel. The descriptive statistics of the variables used in our work are as follows.

Table 2. Descriptive statistics for variables.

\begin{tabular}{cccccccc}
\hline & MM2 & CC & QR & RL & SP & OC & PIBCOST \\
\hline Mean & 17.53404 & -1.198876 & -1.056756 & -1.184418 & -0.742412 & 85.82486 & $1.35 \mathrm{E}+10$ \\
Maximum & 44.13840 & -0.590741 & -0.114754 & -0.223633 & 0.407774 & 165.6460 & $3.80 \mathrm{E}+10$ \\
Minimum & 5.920290 & -1.825740 & -1.480770 & -1.816510 & -2.699190 & 31.49420 & $1.50 \mathrm{E}+09$ \\
Std. Dev. & 6.732637 & 0.273381 & 0.312307 & 0.351127 & 0.787388 & 37.70871 & $8.34 \mathrm{E}+09$ \\
Jarque-Bera & 38.23164 & 0.119289 & 14.74237 & 9.738154 & 6.174578 & 6.489470 & 9.936237 \\
Probability & 0.000000 & 0.942099 & 0.000629 & 0.007680 & 0.045625 & 0.038979 & 0.006956 \\
Observations & 102 & 102 & 102 & 102 & 102 & 102 & 102 \\
\hline
\end{tabular}

Source: Authors based on results obtained from BEAC data.

Table 2 highlights the results of the descriptive statistics for the central tendency (mean, maximum, and minimum) and dispersion (standard deviation) of the variables under study. According to these results, the means were 17.53404, $-1.198876,-1.056756,-1.184418,-0.742412,85.82486$ and 1.35E+10 for MM2, corruption control, quality of regulation, rules and laws, political stability, trade openness and GDP, respectively. With regard to the dispersion of the variables around their respective averages, the results reveal a low concentration of the variables around the average. This result confirms the heterogeneity of CEMAC countries in terms of the variables used in the analysis. The Jarque-Bera test is conclusive only for one variable (control of corruption). This suggests that only 
this variable follows a normal law. However, given the large number of observations (102), based on the law of large numbers, we can conclude that all the variables tend towards a normal law, which allows us to continue our analysis.

Regarding the relationship between the endogenous variable and the explanatory variables, the results in Table 3 suggest a positive relationship between MM2 and all the explanatory variables. Indeed, the correlation coefficient between MM2 and the explanatory variables is positive ( 0.331211 between MM2 and control of corruption, 0.022190 between MM2 and quality of regulation, 0.238541 between MM2 and rules and laws, 0.041631 between MM2 and political stability, 0.081981 between MM2 and degree of openness, 0.123474 between MM2 and GDP), which means that MM2 evolves in the same direction as the explanatory variables. However, since correlation does not mean causality, this relationship must be confirmed by econometric study.

Table 3. Correlation coefficient between variables.

\begin{tabular}{cccccccr}
\hline \multicolumn{1}{c}{ MM2 } & CC & QR & RL & SP & OC & PIBCOST \\
\hline MM2 & 1.000000 & & & & & & \\
\hline CC & 0.331211 & 1.000000 & & & & & \\
& $\mathbf{0 . 0 0 0 7}$ & & & & & & \\
\hline QR & 0.022190 & 0.722707 & 1.000000 & & & & \\
& $\mathbf{0 . 8 2 4 8}$ & $\mathbf{0 . 0 0 0 0}$ & & & & & \\
\hline \multirow{2}{*}{ RL } & 0.238541 & 0.711320 & 0.817969 & 1.000000 & & & \\
& $\mathbf{0 . 0 1 5 8}$ & $\mathbf{0 . 0 0 0 0}$ & $\mathbf{0 . 0 0 0 0}$ & & & & \\
\hline \multirow{2}{*}{ SP } & 0.041631 & 0.118204 & 0.364309 & 0.645202 & 1.000000 & & \\
& $\mathbf{0 . 6 7 7 8}$ & $\mathbf{0 . 2 3 6 7}$ & $\mathbf{0 . 0 0 0 2}$ & $\mathbf{0 . 0 0 0 0}$ & & & \\
\hline \multirow{2}{*}{ TDOPS } & 0.081981 & -0.224651 & -0.251324 & 0.067562 & 0.428321 & 1.000000 & \\
& $\mathbf{0 . 4 1 2 7}$ & $\mathbf{0 . 0 2 3 2}$ & $\mathbf{0 . 0 1 0 8}$ & $\mathbf{0 . 4 9 9 9}$ & $\mathbf{0 . 0 0 0 0}$ & & \\
\hline \multirow{2}{*}{ PIBCOST } & 0.123474 & 0.083335 & 0.373092 & 0.440673 & 0.486351 & -0.033977 & 1.000000 \\
& $\mathbf{0 . 2 1 6 3}$ & $\mathbf{0 . 4 0 5 0}$ & $\mathbf{0 . 0 0 0 1}$ & $\mathbf{0 . 0 0 0 0}$ & $\mathbf{0 . 0 0 0 0}$ & $\mathbf{0 . 7 3 4 6}$ & \\
\hline
\end{tabular}

Source: Authors' estimates.

\subsection{Unit Root Test}

Before estimating the relationship between institutional quality and financial development, it is necessary to test the stationarity of the data. It should be noted that there are a multitude of tests for the stationarity of panel data. However, for the purposes of our study, we will use the tests of Levin, Lin and Chu (2002) and Im, Pesaran and Shin (2003). It should be noted that the LLC test is a first-generation test because it deals with the homogeneous specification of the autoregressive root. It allows us to control the heterogeneity of the panel. Thus, if the unit root hypothesis is not validated, the alternative hypothesis of a homogeneous autoregressive root cannot be automatically accepted.

To solve this problem, we use the IPS test, which is a second-generation test. Under the alternative hypothesis, this test allows not only heterogeneity of the autoregressive root but also relative heterogeneity regarding the presence of a 
unit root in the panel (Hurlin, 2004). The LLC test adopts the null hypothesis of a unit root using the specification of Dickey and Fuller (1981) and does not account for the autocorrelation of residuals. The IPS test can address this shortcoming. Both tests are stable and efficient and remain applicable to small panel data models. The analysis of Table 4 below shows that MM2, CC, QR and RL are level stationary, while the other variables have a unit root. All these variables become stationary when the first difference is considered. In this case, it would be judicious to test the long-term relationship that could exist between these variables through a panel cointegration test.

Table 4. Stationarity test results.

\begin{tabular}{cccccccc}
\hline & IMM2 & CC & QR & RL & SP & IOC & lPIBCOST \\
\hline \multicolumn{7}{c}{ Level variables } \\
LLC & -2.6579 & $-4.4233^{* * *}$ & $-5.0191^{*}$ & -3.8752 & -3.3711 & -2.9831 & -1.9440 \\
IPS & -0.9646 & $-2.1718^{* * *}$ & $-2.5358^{*}$ & $-2.2635^{*}$ & -1.9847 & -1.8022 & -1.8473 \\
\hline \multicolumn{7}{c}{ Variables in first difference } \\
LLC & $-8.3622^{*}$ & $-8.1474^{*}$ & $-8.7891^{*}$ & $-8.0787^{*}$ & $4.6902^{* *}$ & $-8.1094^{*}$ & $-7.2891^{*}$ \\
IPS & $-3.7392^{*}$ & $-4.3008^{*}$ & $-5.6985^{*}$ & $-4.5118^{*}$ & $4.6902^{*}$ & $-5.7026^{*}$ & $-2.7525^{*}$ \\
\hline
\end{tabular}

Source: Authors' estimates; ${ }^{* * *} p<0.01,{ }^{* *} p<0.05,{ }^{*} p<0.1$.

\subsection{Cointegration Test}

To test the cointegration of the variables, we adopt the Pedroni (1999) test, which is widely used in the literature. This test considers four-panel statistics and three-panel group statistics to test the null hypothesis of no cointegration against the alternative hypothesis of cointegration.

Table 5 below shows that with the exception of the panel v-statistic, panel rho-statistic, and group rho-statistic, all statistics reject the null hypothesis of no cointegration. At this stage, we can conclude that there is a long-term relationship between institutional quality and financial development at the panel level.

Table 5. Cointegration test results.

\begin{tabular}{|c|c|c|c|c|}
\hline \multicolumn{5}{|c|}{ Alternative hypothesis: common AR coefficients (within-dimension) } \\
\hline & \multicolumn{4}{|c|}{ Weighted } \\
\hline & Statistic & Prob. & Statistic & Prob. \\
\hline Panel v-Statistic & -0.157967 & 0.5628 & -0.697279 & 0.7572 \\
\hline Panel rho-Statistic & 2.733561 & 0.9969 & 2.597393 & 0.9953 \\
\hline Panel PP-Statistic & -3.479296 & 0.0003 & -4.687421 & 0.0000 \\
\hline Panel ADF-Statistic & -2.479796 & 0.0066 & -2.769241 & 0.0028 \\
\hline \multicolumn{5}{|c|}{ Alternative hypothesis: individual AR coefficients (between-dimension) } \\
\hline & Statistic & Prob. & & \\
\hline Group rho-Statistic & 3.405892 & 0.9997 & & \\
\hline Group PP-Statistic & -8.505508 & 0.0000 & & \\
\hline Group ADF-Statistic & -3.493142 & 0.0002 & & \\
\hline
\end{tabular}

Sources: Authors' estimates. 


\section{Analysis and Discussion of the Results}

The results of our estimation obtained using the DOLS technique suggest that the variation in the explanatory variables explains $79.88 \%$ of the variation in financial development. Moreover, Wald's statistic is significant at the $1 \%$ threshold, which rules out the existence of the autocorrelation of errors. Thus, the model proves to be of good quality, and the results are open to interpretation (Table 6).

Table 6. DOLS estimation results.

\begin{tabular}{|c|c|c|c|c|}
\hline Variables & Coefficients & St Error & t-value & Probabilities \\
\hline Quality of regulation & $-1.029023^{*}$ & 0.3640882 & -2.83 & 0.005 \\
\hline Control of corruption & $0.9361411^{\star}$ & 0.3555546 & 2.63 & 0.008 \\
\hline Political stability & $-0.3228339^{\star}$ & 0.1335763 & -2.42 & 0.016 \\
\hline Rules and laws & $0.9062091^{*}$ & 0.3101093 & 2.92 & 0.003 \\
\hline $\operatorname{Ln}$ (trade openness) & 0.2302134 & 0.3166055 & 0.73 & 0.467 \\
\hline $\operatorname{Ln}(\mathrm{GDP})$ & 0.1333766 & 0.1949469 & 0.68 & 0.494 \\
\hline \multicolumn{5}{|c|}{$N=78$} \\
\hline \multicolumn{5}{|c|}{ Wald chi2 $(6)=40.55$} \\
\hline \multicolumn{5}{|c|}{ Prob $>$ chi $2=0.000$} \\
\hline \multicolumn{5}{|c|}{ Pseudo $\mathrm{R}^{2}=0.68$} \\
\hline & R-Squ & $=0.7988$ & & \\
\hline
\end{tabular}

*denotes significance at the $5 \%$ level. Source: Authors' estimates.

These results yield two major findings. First, regulatory quality and political stability hinder financial development in the CEMAC, and second, corruption control and compliance with regulations and laws are a driving force for the financial development of CEMAC member countries.

Quality of Regulation and Political Stability: $A$ hindrance to the CEMACs financial development

The present situation is justified by the fact that, according to the results, the coefficients assigned to the institutional variables ( $\mathrm{QR}$ and $\mathrm{SP}$ ) are negative and significant at the $5 \%$ level. This suggests that an increase in the latter reduces the level of development of the financial system in the CEMAC. Thus, an improvement of one percentage point in the institutional variables (RQ and SP) in the CEMAC zone, all other things being equal, leads to a reduction of approximately 1.029023 and 0.3228339 points, respectively, in the level of financial development. These results obtained for the CEMAC reinforces those obtained by Bodjongo and Juliot (2012), who showed that the poor quality of institutions in CEMAC countries explains their low level of financial development. However, they are in contrast to those of Anayiotos and Toroyan (2009) and Ayadi et al. 
(2013), which show that good quality institutions (property rights and political stability, good governance and adequate implementation of financial reforms) have a positive impact on the financial development of Sub-Saharan African countries and northern and southern Mediterranean countries, respectively.

In the case of CEMAC countries, this low level of financial development is explained by the fact that the implementation of policies and regulations to promote the private sector has not yet produced the expected results. Thus, political stability in this area has not yet reached the threshold level at which it can begin to have a positive effect on financial development. In CAR, for example, the indicator of political stability and nonviolence was -2.7 in 2014. This indicates a very pronounced level of deterioration in political stability and nonviolence.

\section{$\checkmark$ Control of Corruption and Compliance with Regulations and Laws. A driving force for the financial development of CEMAC member coun- tries}

Statistically, this is justified by the fact that the coefficients of the indicators of institutional quality (CC and RR) are positive and significant at the $5 \%$ level; this highlights a positive relationship between these variables (CC and RL) and financial development in the CEMAC zone. All other things being equal, the results show that an improvement of one percentage point in these indicators leads to increases of approximately 0.9361411 and 0.9062091 points, respectively, in the level of financial development. Thus, the hypothesis is verified. The results are in line with the work of some authors, such as Gazdar (2011), who shows that institutional factors (rule and law, democratic credibility, and quality of bureaucracy) stimulate financial development in MENA countries. However, they contrast with those of Demetriades and Fielding (2009), who consider corruption and political instability to be major challenges to financial development.

In our study area, the CEMAC, this is because the efforts countries have taken to control corruption have retained the confidence of financial institutions and stimulated the supply and demand for financial services. Similarly, the strengthening of the legal protection of creditors' rights and the reduction in information asymmetries regarding borrowers' repayment capacity justify this result.

\section{Conclusion and Policy Implications}

The role of institutions in the financial development of countries is still an open issue. Thus, the institutional framework is an essential factor in the development of financial systems. The purpose of this work was, on the one hand, to analyze the role of the quality of institutions in the financial development of CEMAC countries and, on the other hand, to outline economic policy implications. To this end, the use of panel data over the period 2002-2018 (for all CEMAC coun- 
tries) and the DOLS technique was favored. After the analyses were carried out, two results were obtained. On the one hand, the institutions in the CEMAC countries constitute a hindrance to financial development. This weakening of the level of financial development is observed when considering the institutional indicators quality of regulation and political stability. On the other hand, institutions in the CEMAC zone are a driving force behind financial development, as measured by the institutional indicators corruption control and rule of law.

This study shows that the quality of institutions is an essential factor in the financial development of CEMAC countries. Therefore, it would be necessary to implement mechanisms to improve the quality of institutions in CEMAC countries so that they contribute to their financial development. In other words, continuing to control corruption, strengthening the legal protection of creditors' rights, and putting in place sound policies and regulations to promote the private sector in CEMAC member states means providing them with solid institutions. However, this overall situation could conceal disparities within the area, hence the need to conduct research by country in order to identify possible peculiarities in financial development.

\section{Conflicts of Interest}

The authors declare no conflicts of interest regarding the publication of this paper.

\section{References}

Acemoglu, D., Johnson, S., \& Robinson, J. A. (2001). The Colonial Origins of Comparatives Development: An Empirical Investigation. The American Economic Review, 91, 1369-1401. https://doi.org/10.1257/aer.91.5.1369

Agyemang, O. S., Gatsi, J. G., \& Ansong, A. (2018). Institutional Structures and Financial Market Development in Africa. Cogent Economics \& Finance, 6, Article ID: 1488342. https://doi.org/10.1080/23322039.2018.1488342

Ahokpossi, C., Ismail, K., Karmarkar, S., \& Koulet-Vickot, M. (2012). Financial Depth in the ZAEMU: Benchmarking against Frontier SSA Countries. IMF Working Paper, 13/161. https://doi.org/10.5089/9781484309391.001

Anayiotos, G. C., \& Toroyan, H. (2009). Institutional Factors and Financial Sector Development: Evidence from Sub-Saharan Africa. IMF Working Paper WP/09/258. https://doi.org/10.5089/9781451874044.001

Arestis, P., Demetriades, P., Fattouh, B., \& Mouratidis, K. (2002). The Impact of Financial Liberalization Policies on Financial Development: Evidence from Developing Economies. International Journal of Finance and Economies, 7, 109-121.

https://doi.org/10.1002/ijfe.181

Ayadi, R., Arbake, E., Ben Naceur, S., \& De Groen, W. P. C. (2013). Determinants of Financial Development across the Mediterranean (27 p). Mediterranean Prospects Technical Report No. 29.

Béji, S. (2009). Le développement financier pour les pays du sud de la méditerranée à l'épreuve de la mondialisation. Thèse de Doctorat, Université de Paris XIII-Nord. 
Béji, S., \& Youssef, D. (2010). La place de la régulation bancaire dans le développement bancaire et la croissance: une approche institutionnelle pour les pays du Nord et du Moyen Orient. Région et Développement, 32, 212-151.

Bodjongo, M., \& Juliot, M. (2012). Institutional Infrastructures and Financial Development in Zone CEMAC. MPRA Paper No. 37824.

Cherif, M., \& Gazdar, K. (2010). Institutional and Macroeconomic Determinants of Stock Market Development in Mena Region: New Results From a Panel Data Analysis. International Journal of Banking \& Finance, 7, 139-159.

https://doi.org/10.32890/ijbf2010.7.1.8403

Cho, Y. J. (1986). Inefficiencies from Financial Liberalization in the Absence of WellFunctioning Equity Market. Journal of Money, Credit and Banking, 18, 191-199. https://doi.org/10.2307/1992202

Demetriades, P., \& Fielding, D. (2009). Information, Institutions and Banking Sector Development in West Africa. University of Leicester, Working Paper No.09/04.

Dickey, D., \& Fuller, W. A. (1981). Likelihood Ratio Statistics for Autoregressive Time Series with a Unit Root. Econometrica, 49, 1057-1072. https://doi.org/10.2307/1912517

Gazdar, K. (2011). Institution, développement financier et croissance économique dans la région $M E N A$, Thèse de Doctorat en Sciences Economiques, Université de Reims, Champagne-Ardenne.

Ghura, D., Kpodar, K., \& Singh, R. J. (2009). Financial Deepening in the CFA Franc Zone: The Role of Institutions. IMF Working Paper, WP/09/113. https://doi.org/10.5089/9781451872606.001

Girma, S., \& Shortland, A. (2008). The Political Economy of the Financial Development. Oxford Economic Papers, 60, 567-596. https://doi.org/10.1093/oep/gpm040

Goldsmith, R. W. (1969). Financial Structure and Development. New Haven, CT: Yale University Press.

Gries, T., Kraft, M., \& Meierrieks, D. (2009). Linkages between Financial Deepening, Trade Openness and Economic Development: Causality Evidence from Sub-Saharan Africa. World Development, 37, 1849-1860. https://doi.org/10.1016/j.worlddev.2009.05.008

Gurley, J., \& Shaw, E. (1960). Money in a Theory of Finance. Washington DC: Brooking.

Huang, W., \& Temple, J. (2005). Does External Trade Promote Financial Development? Discussion Paper, Bristol: University of Bristol.

Hurlin, C. (2004). Testing Granger Causality in Heterogeneous Panel Data Models with Fixed Coefficients. Document de Recherche, LEO, N 2004-05, Orléans: Université d'Orléans.

Im, K. S., Pesaran, M. H., \& Shin, Y. (2003). Testing for Unit Roots in Heterogeneous Panels. Journal of Econometrics, 115, 53-74. https://doi.org/10.1016/S0304-4076(03)00092-7

Joseph, A. (2002). La réforme du secteur financier en Afrique. Document Technique du Centre de Développement de l'OCDE, Paris.

Kao, C., \& Chen, B. (1995). On the Estimation and Inference for Cointegration in Panel Data When the Cross Section and Time Series Dimensions Are Comparable. Manuscript, New York: Center for Policy Research, Syracuse University.

Kao, C., \& Chiang, M. H. (2001). On the Estimation and Inference of a Cointegrated Regression in Panel Data. In B. H. Baltagi, T. B. Fomby, \& R. Carter Hill (Eds.), Nonstationary Panels, Panel Cointegration, and Dynamic Panels (Advances in Eco-nometrics, Vol. 15) 
(pp. 179-222). Bingley: Emerald Group Publishing Limited. https://doi.org/10.1016/S0731-9053(00)15007-8

La Porta, R., Lopez-de-Silanes, F., Shleifer, A., \& Vishny, R. (1997). Legal Determinants of External Finance. The Journal of Finance, 52, 1131-1150. https://doi.org/10.1111/j.1540-6261.1997.tb02727.x

La Porta, R., Lopez-de-Silanes, F., Shleifer, A., \& Vishny, R. (1998). Law and Finance. Journal of Political Economy, 106, 1113-1155. https://doi.org/10.1086/250042

Law, S. H., \& Azman-Saini, W. (2008). The Quality of Institutions and Financial Development. MPRA Paper (12107).

Law, S. H., \& Habibullah, M. (2009). The Determinants of Financial Development: Institutions, Openness and Financial Liberalization. South African Journal of Economics, 77, 45-58. https://doi.org/10.1111/j.1813-6982.2009.01201.x

Levin, A., Lin, C. F., \& Chu, C. (2002). Unit Root Tests in Panel Data: Asymptotic and Finite Sample Properties. Journal of Econometrics, 108, 1-24. https://doi.org/10.1016/S0304-4076(01)00098-7

Mahar, J., \& Williamson, M. (1998). A Survey of Financial Liberalization. Essays in International Finance, No. 211, Princeton, NJ: Department of Economics, Princeton University.

Mark, N. C., \& Sul, D. (2003). Cointegration Vector Estimation by Panel DOLS and Long-Run Money Demand. Oxford Bulletin of Economics and Statistics, 65, 655-680. https://doi.org/10.1111/j.1468-0084.2003.00066.x

Mckinnon, R. I. (1973). Money and Capital in Economic Development. Washington DC: The Brooking Institution.

North, D. C. (1990). Institutions, Institutional Change, and Economic Performance. Cambridge: Cambridge University Press. https://doi.org/10.1017/CBO9780511808678

Pedroni, P. (1999). Critical Values for Cointegration Tests in Heterogenous Panels with Multiple Regressors. Oxford Bulletin of Economics and Statistics, 61, 653-670.

Pedroni, P. (2001). Fully Modified OLS for Heterogeneous Cointegrated Panels. In B. H. Baltagi, T. B. Fomby, \& R. Carter Hill (Eds.), Nonstationary Panels, Panel Cointegration, and Dynamic Panels (Advances in Econometrics, Vol. 15) (pp. 93-130). Bingley: Emerald Group Publishing Limited. https://doi.org/10.1016/S0731-9053(00)15004-2

Rajan, R., \& Zingales, L. (2003). The Great Reversals: The Politics of Financial Development in the Twentieth Century. Journal of Financial Economics, 69, 5-50. https://doi.org/10.1016/S0304-405X(03)00125-9

Roe, M. J., \& Siegel, J. I. (2009). Finance and Politics: A Review Essay Based on Kenneth Dam's analysis of Legal Traditions in the Law-Growth Nexus. Journal of Economic Literature, 47, 781-800. https://doi.org/10.1257/jel.47.3.781

Schumpeter, J. (1912). The Theory of Economic Development. Cambridge MA: Harvard University Press.

Shaw, E. S. (1973). Financial Deepening in Economic Growth. New York: Oxford University Press.

Stiglitz, J., \& Weiss, A. (1981). Credit Rationing in Markets with Imperfect Information. American Economic Review, 71, 393-410.

Tapsoba, J. A. (2009). Intégration Monétaire Africaine et Changements Structurels: Commerce, Partage des risques et Coordination budgétaire (p. 216). Sciences de l'Homme et Société, Université e d'Auvergne-Clermont-Ferrand I.

Van Wijnbergen, S. (1983). Interest Rate Management. Journal of Monetary Economics, 
12, 433-452. https://doi.org/10.1016/0304-3932(83)90063-6

Yasmina, G., \& Mohamed, A. (2016). Déterminants du développement financier dans la region du MENA (1996-2011): Evidence d'un panel. El-Bahith Review, 16, 111-130. 